\title{
Decolonisation in Aotearoa: Education, Research and Practice. (2016). Edited Collection by Jessica Hutchings and J Lee-Morgan
}

\author{
NZCER Press. Wellington New Zealand. 226 pp., ISBN: 978-0- \\ 947509-17-0 (softcover). E-book versions available: Digital edi- \\ tions of the books are available from www.mebooks.co.nz and \\ www.amazon.com
}

\section{Adreanne Ormond ${ }^{1}$ (D)}

Received: 4 December 2017/ Accepted: 25 May 2018/Published online: 4 June 2018

(C) The Author(s) 2018

Decolonisation is understood by indigenous people as a cultural resurgence occurring within their community and nation across the globe, involving the reclamation of indigenous statehood and the associated cultural, spiritual, political and economic sovereignty (Alfred 2008). The phrase decolonisation was popularised through the work of the Māori scholar-activist Professor Linda Tuhiwai Smith in her book, Decolonising Methodologies (1999). As a Māori, Smith wrote from an ontology influenced by her culture and, therefore, her scholarship with decolonisation has special relevance to Māori people and their community within Aotearoa/New Zealand because of its philosophical connection to Māori society, their legacy of resistance, and vision of tino rangatiratanga or self-determination.

Enter Jessica Hutchings and Jenny Lee-Morgan, who represent another generation of Māori decolonisation educators. Together, these two young intellectuals pick up the wero or challenge to continue scholarly provocation toward the settler colonial state through their expansive edited collection, Decolonisation in Aotearoa: Education: Research and Practice (2016). The publication is timely; it coincides with 200 years of schooling within Aotearoa and discusses how the education system has been used to colonise, assimilate and domesticate Māori into the values and society of the settler state. In keeping with the title, the book also focuses on decolonisation through exploring the emancipatory transformation that is occurring within institutions, including education, iwi, hapu, whānau and community. With fifteen chapters, the contributing authors represent some of the renowned thought leaders and scholarly-activists, researchers, practitioners and community workers within Māori society. Among the authors is the now deceased Professor

Adreanne Ormond

adreanne.ormond@vuw.ac.nz

1 Victoria University of Wellington, Wellington, New Zealand 
Ranginui Walker-whose unfailing commitment to Māori's assertion of tino rangatiratanga was the embodiment of his renowned text, $\mathrm{Ka}$ Whawhai Tonu Mātou: Struggle Without End (Walker 2004).

A book that focuses on decolonisation within Aotearoa should privilege a Māori worldview and this text meets the critical criteria by been underpinned by Kaupapa Māori or Māori principles. It is written in the traditional Māori narrative style of pūrākau which is used in story telling about significant historical people and places. Pūrākau is also useful as a methodological and pedagogical tool (Lee 2008) and the book utilises these elements by presenting the grievous cultural annihilation of Māori through story-work. Thus, although factual, the content does not overburden the reader and allows for reflection and contemplation with the purpose of promoting engagement that is transformational for the individual, community, and wider society.

Although consideration of the reader is given, the authors are rigorous in continually questioning assumptions based on colonial ontology that have led to the inequitable relationships of power between Māori, the settler state and Pākeha. Critical questions include: Within Aotearoa, whose political and social agenda has the education system served? What do Māori educators, community practitioners, iwi, hapu and whānau view as constituting education? How are Māori responding to the changing political agenda and diverse needs within their community?

The book stands out with a beautiful cover graphic provided by leading contemporary Māori artist Robin Kahukiwa; the content is divided into three sections with the foreword appropriately written by the noted Māori decolonisation scholar Linda Tuhiwai Smith. The first section (Māori in education) orientates the reader to the legacies of British imperialism with a critical analysis of the education system, constitution, and Christian church as tools the settler state used in the colonisation and assimilation of Māori (Walker, Chapter One; Jackson, Chapter Two; and Mikaere, Chapter Three). With the political discourse of education and religion established, the book turns the monocultural education system on its head and provides case studies of Kaupapa Māori pedagogy and praxis (Lee-Morgan, Chapter Five), including how it has been used to create transformative spaces where Māori can flourish (Tiakiwai, Chapter Four; Murphy, Chapter Six; and Rāwiri, Chapter Ten). Rangatahi represent the younger generation and are critical to any discussion about social transformation. An excellent case study of youth engagement with constitutional discourse provides hope for future rangatiratanga (Jackson, Chapter Two; and Tawhai, Chapter Six).

The second section of the book (Māori in research) accomplishes another important task by demystifying the political agenda of knowledge production and transmission (education). This is important because central to decolonisation and transformation is unmasking the dehumanising injustice embedded in the schooling system that denied and undermined the indigenous Māori knowledge systems, including language. Therefore, fundamental to self-determination is the reclamation of Māori knowledge traditions. The contributors (Pihama, Chapter Eight, LeePenehira, Chapter Nine; and Rāwiri, Chapter Ten) grapple with the complex necessity of placing Māori values and traditions central to research, praxis and pedagogy. Examples are provided as to how Māori knowledge is increasingly 
moving from the margins to the centre, to be taught and utilised within institutions and community.

The third and final section (Māori in practice) questions what knowledge is relevant to Māori community and unapologetically encourages community to define what they view as meaningful education? These chapters consider the multiformity and evolving needs of the Māori community and include topics that are usually not included within a standard educational text. These include, traditional food production (Hutchings, Chapter Thirteen), Māori media (Smith, Chapter Twelve) and a division of three chapters that focus on female health and social wellbeing (Simmonds \& Gabel, Chapter Eleven; Murphy, Chapter Fourteen; and Broughton, Chapter Fifteen).

The book is provocative, illuminating and inspiring. It deserves to be read by scholars and educators alike, because it has the potential to shift how they approach the political issue of indigenous rights, where a large part of this is Māori and schooling. This edited collection skilfully communicates the decolonising project to another generation and renews the struggle for tino rangatiratanga by challenging the commitment of the state and government to Māori, while also celebrating the strength, resources, political strategy and innovative power of indigenous peoples.

\section{Glossary}

Hapu

Iwi

Kaupapa Māori

Pūrākau

Rangatahi

Rangatiratanga

Tino rangatiratanga

Wero

Whānau
A collection of related whānau

Tribe

Māori philosophy and principles

Kāupapa Māori storytelling

Young people

Leadership

Self-determination

Challenge

Family

Open Access This article is distributed under the terms of the Creative Commons Attribution 4.0 International License (http://creativecommons.org/licenses/by/4.0/), which permits unrestricted use, distribution, and reproduction in any medium, provided you give appropriate credit to the original author(s) and the source, provide a link to the Creative Commons license, and indicate if changes were made.

\section{References}

Alfred, T. (2008). Peace, power, righteousness. An indigenous manifesto (2nd ed.). Don Mils: Oxford University Press.

Lee, J. B. J. (2008). Ako: Pūrākau of Māori secondary school teachers' work in secondary schools. Unpublished doctoral thesis. The University of Auckland, New Zealand.

Smith, L. (1999). Decolonising methodologies: Research and indigenous peoples (1st ed.). London: Zed Books.

Walker, R. (2004). Ka Whawhai Tonu Mātou: Struggle without end (Revised ed.). Auckland: Penguin Books. 